\title{
Personality Traits and Misdemeanor of Adolescents in a Catholic High School
}

\author{
Josefa Darling G. Sombero ${ }^{1}$ and Ma. Wilma M. Maravilla² \\ ${ }^{1}$ Don Bosco Technical Institute, Victorias City, Philippines \\ 2University of Negros Occidental-Recoletos, Bacolod City, Philippines
}

\section{Article history \\ Submitted: 8 July 2020 \\ Revised: 28 October 2020 \\ Accepted: 12 November 2020}

\section{Keywords}

Guidance and Counseling

Personality Traits

Misdemeanor

Adolescents

Descriptive-Correlational

Negros Occidental

Introduction. Distinctive personality traits account for every person, who they are, and how they behave. These have impacts on the way people perceive the world. Like adults, children and adolescents can be described in terms of personality traits such as characteristics, patterns of thinking, feeling, and behaving. This study reports the personality traits and extent of a misdemeanor of high school students. Also, it seeks to find out if one's personality traits affect the behavioral tendencies and vice-versa, how these traits develop across childhood and adolescence, and how they relate in the transition of adolescence period that involves changes in biological, socio-emotional, and wellbeing. The vast majority of research has focused more on adulthood and is scarcer than adolescent personality traits research. Additionally, the relationship between personality traits and misdemeanor and the demographic variables was also explored.

Methods. With the use of descriptive-correlational research designs, 100 respondents identified with misdemeanor cases answered two standardized questionnaires, such as the Normative Deviance Scale (NDS), in measuring misdemeanor and the Big Five Inventory (BFI), which provided the data for this study. Mean, Standard Deviation, frequency count, percentage distribution, and Chi-square were utilized in analyzing the result.

Results. The findings of the study revealed an average level of personality traits and a moderate extent of misdemeanor into the different variables. Alcohol, school misconduct, and vandalism were found as salient misdemeanor acts among respondents. No significant relationship was found between personality traits and demographic variables and between personality traits and students' misdemeanor. Meanwhile, a significant relationship existed between personality traits (extraversion) and birth order, misdemeanor (vandalism) and birth order, and misdemeanor (alcohol) and grade level. This study also reported that a significant finding was found between the extent of misdemeanor and school misconduct. Furthermore, both indirect and direct salient factors attributed to personality traits and misdemeanors were influential to high school students. Among these are family, peer, society, and cultural factors that could shape individuals' development. Moreover, indirect and direct sources could predict personality traits and misdemeanor among demographic variables.

Conclusion. Collaboration with the guidance counselor is an effective way to achieve a positive outcome in using behavior modification. Mastery and using techniques effectively suggest an aid to the students. Likewise, the family of every adolescent plays a vital role in the development of his or her personality traits. With the global modernization that covers every corner of the world, the family systems are somewhat shaken. Parents of adolescents experience difficulties with the rapid changes brought about by advancement. Along with these changes, the victims are often the children affected by parents' radical decisions. The findings of the study suggest that in order to minimize cases of misdemeanor acts, early intervention, personalized program, intensification, reevaluation, strong support of the school, and programs should focus on enhancing self-discipline by getting rid of negative self-talk and fostering self-awareness through activities that could strengthen the students' perceived capability. These activities should aim to create specific and values formation and teach ways of materializing concrete ways to achieve these goals. Also, teachers and discipline 
moderator are recommended to be equipped with various behavior modifications at an early stage of an adolescent misdemeanor that could help curb these social vices.

Practical Value of the Paper. The study significantly contributes to addressing distinctive personality traits that could increase the risk of misdemeanor behavior among high school students. Furthermore, the findings of the study provided baseline information to school administrators, guidance counselors, teachers, and discipline moderator in formulating an intervention program that motivates positive attitude and discipline to manage and cope with behavioral problems.

\section{References}

Amadi, G., Ahamefule, \& Michael O., Tunde, O. T., (2016). Influence of personality and demographic factors on aggressive behaviour among secondary school students. British Journal of Psychology Research Vol.3, No.1, pp. 1-6.

Borghuis, J., Oberski, D., Meeus, \& WHJ, Branje, S. (2017). Big Five personality stability, change, and codevelopment across adolescence and early adulthood. Journal in Personality Psychology. 2017 Oct; 113(4):641-657. doi: 10.1037/pspp0000138, Epub, 2017 Mar 2.

De Bolle, M., De Fruyt, F., \& Terracciano, A. (2015). The emergence of sex differences in personality traits in early adolescence: A cross-sectional cultural study. Journal of Personality and Social Psychology. Author Manuscript.

Heng, WY. Hui, CY. Ting, TP., \& Yin, CT. (2017). The relationship between birth order and the Big Five personality dimensions among psychology students in Universiti Malaysia Sabah. Journal in Psychology. (JPsiKS) 2017, Vol.1, 71-75. E-ISSN: 2600-7819

Markova, S., \& Nikitskaya, E. (2017). Coping strategies of adolescents with deviant behaviour. International Journal of Adolescence and Youth. Doi: 10.1080/02673843.2013.868363

Musthafa, F.F., Putriana, D., \& Latipun (2019). School Belonging as a Moderation of Influence Peer Attachment on School Misconduct of Students. The International Journal of Indian Psychology. ISSN 2348-5396, Vol.7, Issue 1 DIP: $18.01 .052 / 20190701$

Ojeme, A.I. (2017). Some useful ameliorative behavior modification therapies for frequently observed adolescents' misdemeanors in Nigeria. International Journal of Education, Learning, and Development. ISSN: 2054-6300

Schall, J., Wallace, T.L.B., \& Chhuon, V. (2016). "Fitting in" in high school: How adolescent belonging is influenced by locus of control beliefs. International Journal of Adolescence and Youth, 21(4), 462-475. Retrieved from: https// doi.or./10.180/02673843.2013.866148.

Vilalta, C., \& Fondevilla, G. (2017). School Vandalism in Mexico. Journal of School Violence. doi: $1080 / 15388220.2017 .1355809$

Vist, N. V. (2016). Psychological and pedagogical conditions for the prevention of deviant behavior among adolescents. International Journal of Environmental \& Science Education. Vol.11, No. 15, 853\536-8551.

\section{Correspondence:}

Josefa Darling G. Sombero [somberojosefadarling@gmail.com]

http://orcid.org/0000-0002-3681-6883 